\title{
Editor's Commentary
}

WITH ISSUE 1 of 2013, Daniel Rottig and I will assume the duties of Associate Editor and Editor of AIB Insights. We plan some changes over our tenure; one is the establishment of an advisory board that will be geographically oriented. We also plan on involving the board in diversifying Insights articles, to publish a greater number of thematic journal issues on specific topics and current events in specific regions around the world. The Board will also develop a more rigorous review process. Insights is a forum for presenting information and opinions dealing with issues of interest and value to international business academics and practitioners. We invite your contribution.

The focus of this issue is initiating further discussion of defining a Domain for international business study and the Academy of International Business.

\section{Is Defining a Domain for International Business Study Necessary?}

Prof. Lee C. Nehrt, retired Owens-Illinois Professor of International Management, College of Business, Ohio State University is identified as the first person to earn a PhD in International Business, at the Graduate School of Business of Columbia University in 1962 (Elahee, 2007). However, fifty years later, the AACSB (2012) reports only 6 percent of their members offer PhDs in International Business, 19.5 percent MBAs, and 16.1 percent Specialised Masters programmes in IB. AIB Insights is inviting interested parties to contribute manuscripts relating to defining a domain for international business study. International business refers to business activities amongst individuals and businesses that involve the transfer of resources, goods, services, knowledge, skills, or information across national borders. Reading through past academic publications I find (amongst several more of equally influential quality) several articles that address the issue, that you can read for your edification and ideas:

For the twenty-fifth anniversary issue of the Journal of International Business Studies (JIBS): Wright, R.W. \& Ricks, D.A. 1994. Trends in international business research: Twenty-five years later. Journal of International Business Studies, 25(4 (4): 687-701.

And:

Fayerweather, J. 1994. A personal odyssey through the early evolution of international business pedagogy, research, and professional organization. Journal of International Business Studies, 25(1): 1-44.

Buckley, P. 2002. Is the international business research agenda running out of steam? Journal of International Business Studies 33(2): 365373.

Peng, M.W. 2004. Identifying the big question in international business research. Journal of International Business Studies, 35(2), 99-108.

Perhaps reading through these articles will inspire you to contribute your ideas to future issues of Insights.

Ruël, Lee and Visser provide and interesting discussion of the considerations and relationships between government and business, relating commercial diplomacy and international business success.

In response to requests from members attending AIB 2012 in Washington D.C. in the USA, we close the issue with a reprise of the plenary address at the conference, "Rethinking our Roles", by Ray Offenheiser, President of Oxfam America, and winner of the Academy of International Business President's Award.

\section{References}

AACSB, (2012). Business school data trends and 2012 list of accredited schools. Tampa, FL, USA: The Association to Advance Collegiate Schools of Business.

Elahee, M.N. 2007. Lee C. Nehrt (1926-): A pioneering international business scholar. European Business Review, 19(2): 142 - 159. 